\title{
Perlindungan Hukum Terhadap Hak Anak Korban Kekerasan
}

\section{Geatriana Dewi}

Institut Ilmu Sosial dan Budaya Samawa Rea

alifiarufaniza@yahoo.com

\section{Artikel Info}

Tanggal Publikasi

Kata Kunci

Hak Anak Korban

Kekerasan

\section{Abstrak}

Penelitian ini bertujuan untuk memberikan pemahaman mengenai perlindungan hukum terhadap hak anak korban kekerasan berdasarkan peraturan perundangundangan yang berlaku di indonesia. Dari penelitian ini diharapkan dapat memberikan tambahan pemahaman bagi masyarakat kalangan akademisi dan praktisi hukum mengenai pentingnya perlindungan hukum terhadap hak-hak anak korban kekerasan, karena anak adalah generasi penerus untuk kemajuan bangsa dan negara. Selain itu hasil penelitian dapat menjadi pertimbangan bagi masyarakat dan para praktisi hukum untuk melaksanakan tugasnya dalam memberikan perlindungan terhadap anak yang menjadi korban kekerasan. Penelitian ini menggunakan metode pendekatan normatif empiris yaitu pendekatan dengan terlebih dahulu membaca dan menganalisis literatur dan peraturan perundang-undangan yang terkait dengan pokok bahasan. Tehnik pengumpulan data menggunakan data primer dengan wawancara dan studi pustaka.

\section{PENDAHULUAN}

Anak sebagai bagian dari generasi muda merupakan penerus cita-cita perjuangan bangsa sekaligus modal sumber daya manusia bagi pembangunan nasional. Disebutkan dalam Pasal 34 ayat (1) UndangUndang Dasar 1945 bahwa fakir miskin dan anak-anak terlantar dipelihara oleh Negara. Negara mengembangkan sistem jaminan sosial bagi seluruh rakyat dan memberdayakan masyarakat yang lemah dan tidak mampu sesuai dengan martabat kemanusiaan. Negara yang bertanggung jawab atas penyediaan fasilitas pelayanan kesehatan dan fasilitas pelayanan umum yang layak. Dengan adanya jaminan dalam Undang-Undang Dasar 1945 tersebut dapat diartikan bahwa dianggap belum memliki kemampuan untuk berdiri sendiri baik secara rohani, jasmani maupun sosial.

Menjadi kewajiban bagi orang dewasa baik orangtua, keluarga, masyarakat maupun bangsa untuk memberikan jaminan, memelihara dan mengamankan kepentingan anak serta melindungi dari gangguan yang datang dari luar maupun dari anak itu sendiri. Asuhan anak, terutama menjadi kewajiban dan tanggungjawab orangtua di lingkungan keluarga akan tetapi demi kepentingan kelangsungan tata sosial maupun untuk kepentingan anak itu sendiri, perlu adanya campur tangan pemerintah.

Sebetulnya usaha perlindungan terhadap anak telah cukup lama dibicarakan baik di Indonesia maupun di dunia internasional. Perhatian mengenai masalah perlindungan anak ini tidak akan pernah berhenti karena disamping merupakan masalah universal juga karena dunia ini akan selalu diisi oleh

anak-anak. Sepanjang dunia tidak sepi dari anak-anak, selama itu pula masalah anak akan selalu dibicarakan.

Disebutkan dalam Pasal 1 butir 1 Undang-Undang Nomor 23 Tahun 2002 bahwa yang dimaksud dengan perlindungan anak adalah segala kegiatan untuk menjamin dan melindungi anak dan hakhaknya agar dapat hidup, tumbuh, berkembang dan berpartisipasi secara optimal sesuai dengan harkat dan mastabat kemanusiaan serta mendapat perlindungan dari kekerasan dan diskriminasi. 
Seiring dengan perkembangan jaman, perlindungan terhadap anak semakin dituntut pelaksanaannya. Perkembangan teknologi dan budaya yang terjadi dewasa ini telah memunculkan beberapa efek positif dan negatif dalam kehidupan masyarakat Indonesia. Efek atau dampak positif dari perkembangan teknologi dan budaya adalah semakin canggihnya teknologi yang ada pada saat ini dapat mempermudah dalam pemenuhan kebutuhan hak-hak anak sedangkan efek negatifnya adalah adanya pergaulan bebas dan semakin meningkatnya kejahatan seks atau kekerasan yang terjadi, khususnya yang menimpa anak-anak.

Sebagai gambaran umum terhadap kejahatan seks yang terjadi pada anak. Pada tahun 1996 bahwa data anak yang dieksploitasi di Pulau Lombok 75\% dari 70 responden adalah pada usia anak. Tahun 2001 di Kecamatan Gunung Sari dan Kecamatan Batulayar ditemukan 25 dari 30 anak menjadi korban pencabulan. Tahun 2004-2005 dari banyaknya bentuk kekerasan anak di Bali dan Lombok didapat data bahwa 173 anak pernah menjadi korban para pedopilis.

Pelaku pencabulan terhadap anak adalah pedofil yang terangsang secara seksual terhadap anak dan sangat berhati-hati dalam menyembunyikan perbuatannya. Mereka menyusup dalam masyarakat dengan cara memberi kesan mereka adalah orang baik-baik untuk mendapat kepercayaan orang dewasa untuk mengasuh anak-anak sebagai pengasuh, guru, pelatih olahraga, pelatih pramuka, pembersih rumah dan kebun serta pekerjaan lain yang memungkinkan mereka mendapat waktu bersama anak. Bila orangtua sudah mempercayai bahwa pencabul adalah orang baik, maka anak akan mengikuti persepsi orangtuanya dan dari sinilah pencabulan berulang-ulang dilakukan selalu disertai dengan ancaman untuk merahasiakan serta kekerasan.

Selain hal-hal diatas yang menjadi masalah terpenting adalah bentuk perlindungan yang diberikan kepada korban tindak pidana kekerasan. Dalam pengaturan hukum Indonesia, korban selalu menjadi pihak yang paling dirugikan. Bagaiamana tidak, selain korban telah menderita kerugian akibat kejahatan yang menimpa dirinya baik secara materiil, fisik maupun psikologis korban juga harus menanggung derita berganda karena tanpa disadari sering diperlakukan hanya sebagai sarana demi terwujudnya sebuah kepastian hukum misalnya harus kembali mengemukakan, mengingat bahkan mengulangi (merekonstruksi) kejahatan yang pernah menimpanya pada saat sedang menjalani proses pemeriksaan baik ditingkat penyidikan maupun setelah kasusnya diperiksa di pengadilan.

Keberpihakan hukum terhadap korban yang terkesan timpang jika dibandingkan dengan tersangka (terdakwa) terlihat dari adanya beberapa peraturan perundang-undangan yang lebih banyak memberikan "hak istimewa" kepada tersangka (terdakwa) dibandingkan kepada korban.

Dalam kaitannya dengan tindak pidana pencabulan, anak-anak merupakan korban mayoritas dalam hal ini padahal mereka merupakan karunia Tuhan Yang Maha Esa yang tidak dapat tergantikan oleh apapun dan jika dilihat dari sudut pandang kehidupan berbangsa dan bernegara, anak merupakan masa depan dan generasi penerus bangsa sehingga setiap anak berhak mendapatkan perlindungan baik itu dari kekerasan, diskriminasi. Tapi pada kenyataannya anak seringkali menjadi objek kejahatan. Hal ini tidak bias terlepas dari sifat anak yang masih lemah sehingga sangat mudah bagi pelaku kejahatan untuk memperdaya korban.

\section{METODE PENELITIAN}

Penelitian ini menggunakan pendekatan normatif empiris yaitu membaca dan menganalisis literatur dan peraturan perundang-undangan tentang Perlindungan Hukum Terhadap Anak dan halhal yang terkait dengan pokok bahasan tersebut. Penelitian ini dilakukan di Lembaga Perlindungan Anak Mataram dan di Lapas Anak Kelas II Mataram.

Dalam penelitian ini menggunakan 2 (dua) sumber data yaitu yang pertama Sumber Data Primer adalah data yang diperoleh di lapangan yang terkait dengan penyebab terjadinya kekerasan terhadap 
anak dan dampak dari kekerasan tersebut terhadap keluarga dan masyarakat sekitar dan yang kedua Sumber Data Sekunder yaitu data yang diperoleh oleh peneliti dari subyek penelitian misalnya diperoleh dari hasil-hasil penelitian, makalah, seminar, buku-buku referensi, artikel dalam berbagai majalah ilmiah, surat kabar, jurnal penelitian di bidang hukum dan dokumen-dokumen lain yang relevan dengan makalah yang diteliti.

Pendekatan yang dilakukan dalam penelitian ini menggunakan Pendekatan Sosiologis yaitu suatu pendekatan dengan memperhatikan dan mengkaji perilaku dan perkembangan masyarakat yang terkait dengan faktor-faktor penyebab terjadinya kekerasan terhadap anak dan dampak dari kekerasan tersebut terhadap keluarga dan masyarakat dan yang kedua melalui Pendekatan Konseptual yang dilakukan dengan mengkaji atau bepeoman pada literatur yang berupa peraturan perundang-undangan yang erat kaitannya dengan tinjauan yuridis tentang penyebab terjadinya kekerasan terhadap anak.

Tekhnik pengumpulan data dalam penelitian ini dilakukan dengan tiga cara yakni observasi, wawancara yang merupakan proses tanya jawab secara langsung, bebas, terpimpin dan dokumentasi yang digunakan untuk mendapatkan data-data yang berkaitan dengan faktor-faktor penyebab terjadinya kekerasan terhadap anak dan dampak dari kekerasan tersebut terhadap keluarga dan masyarakat sekitar.

Analisis data dalam penelitian ini akan dilakukan setelah menempuh langkah-langkah yakni pengumpulan data, reduksi data, yakni dengan mengambil data yang terkait langsung dengan tujuan penelitian. Penyajian data dalam kalimat yang lugas dan mudah dicerna selanjutnya dianalisa dengan menggunakan analisis kwalitatif sehingga dari analisa tersebut akan menghasilkan analisa deskriptif yakni dalam bentuk uraian-uraian guna mengungkap kebenaran data yang diajukan.

\section{HASIL DAN PEMBAHASAN}

\section{Faktor Penyebab Tindak Pidana Kekerasan Terhadap Anak}

Kekerasan terhadap anak adalah tindakan orang dewasa terhadap anak dengan cara yang disadari ataupun tidak yang berakibat menganggu proses tumbuh kembang anak. Sehingga dapat menimbulkan cacat fisik, mental bahkan kematian anak. Bentuk-bentuk kekerasan terhadap anak menurut Mieke Diah Anjar Yanti adalah sebagai berikut: a) Kekerasan fisik adalah tindakan yang menyebabkan rasa sakit atau potensi menyebabkan sakit yang dilakukan oleh orang lain, dapat terjadi sekali atau berulang kali seperti dipukul, ditendang, ditempeleng, dijewer, dicubit, dilempar dengan benda keras, dijemur dibawah terik sinar matahari; b) Kekerasan seksual adalah keterlibatan anak dalam kegiatan seksual yang tidak dipahaminya seperti perlakuan tidak senonoh dari orang lain, kegiatan yang menjurus pada pornografi, perkataan-perkataan porno, perbuatan cabul dan persetubuhan pada anak-anak yang dilakukan orang lain dengan tanpa tanggung jawab, tingkatan mendorong atau memaksa anak terlibat dalam kegiatan seksual yang melanggar hukum seperti dilibatkan pada kegiatan prostitusi; c) Kekerasan psikis dalah segala sesuatu yang dapat menyebabkan terhambatnya perkembangan psikologis anak seperti kata-kata yang mengancam, menakut-nakuti, berkata-kata kasar, mengolok-olok, perlakuan diskriminatif, membatasi kegiatan sosial dan kreasi; d) Kekerasan ekonomi (eksploitasi komersial) adalah penggunaan anak untuk bekerja dan kegiatan lainnya demi kebutuhan orang tuanya atau orang lain seperti menyuruh anak bekerja secara berlebihan, menjerumuskan anak kepada dunia prostitusi untuk kepentingan ekonomi; e) Tindak pengabaian dan penelantaran adalah ketidak pedulian orang tua, orang yang bertanggungjawab atas anak pada kebutuhan mereka seperti pengabaian pada kesehatan anak, pengabaian dan penelantaran pada pendidikan anak, pengabaian pada pengembangan emosi, penelantaran pada pemenuhan gizi, pengabaian dan penelantaran pada penyediaan perumahan, pengabaian pada kondisi keamanan dan kenyamanan.

Bentuk-bentuk kekerasan terhadap anak menurut Mufidah ada tujuh bentuk kekerasan yang lazim ditemukan, diantaranya sebagai berikut: a) Kekerasan dalam bentuk fisik seperti pemukulan, 
penganiayaan berat yang menyebabkan jatuh sakit, bahkan kematian; b) Kekerasan psikis seperti ancaman, pelecehan, sikap kurang menyenangkan yang menyebabkan rasa takut, rendah diri, trauma, depresi atau gila; c) Kekerasan ekonomi, misalnya menelantarkan anak; d) Kekerasan seksual berbentuk pelecehan seksual, pencabulan dan pemerkosaan; e) Eksploitasi kerja dan bentuk pekerjaan terburuk untuk anak; f) Eksploitasi seksual komersial anak; g) Trafficking (perdagangan) anak

Faktor-faktor penyebab seseorang melakukan kekerasan terhadap anak antara lain sebagai berikut: a) Hambatan dalam perkembangan psikologis yang menyebabkan ketidakmampuan penderita menjalin relasi yang wajar; b) Kecenderungan kepribadian antisosial yang ditandai dengan hambatan perkembangan pola seksual yang matang disertai oleh hambatan perkembangan moral; c) Terdapat kombinasi regresi, ketakutan yang berlebihan, serta rendahnya tekanan etika dan moral

Dari berbagai bentuk kekerasan diatas kita akan melihat beberapa hal dampak yang dapat terjadi: a) Anak mengembangkan pola adaptasi dan keyakinan-keyakinan keliru sesuai dengan sosialisasi yang diterimanya, misalnya anak akan menganggap wajar perilaku orang dewasa, meniru tindakan yang dilakukan kepadanya, menyalahkan ibu atau orang atau dewasa yang mengasuhnya yang dianggapnya tidak membelanya dari hal-hal buruk yang dialaminya. Yang sering terjadi adalah merasa bersalah, merasa menjadi penanggungjawab atas kejadian yang dialaminya, menganggap diri aneh dan terlahir sial (misal, sudah dikutuk untuk selalu mengalami hal buruk dan menyusahkan orang lain dan sebagainya); b) Anak merasa dikhianati. Bila pelaku kekerasan adalah orang dekat dan dipercaya apalagi orangtua sendiri, anak akan mengembangkan perasaan dikhianati dan akhirnya menunjukkan ketakutan dan ketidakpercayaan pada orang-orang lain dan kehidupan pada umumnya. Hal ini akan sangat berdampak pada kemampuan sosialisasi, kebahagiaan dan hampir semua dimensi kehidupan psikologis pada umumnya; c) Stigmatisasi. Disatu sisi masyarakat yang mengetahui sejarah kehidupan anak akan melihatnya dengan kacamata berbeda, misalnya dengan rasa kasihan sekaligus merendahkannya atau menghindarinya. Di sisi lain anak mengembangkan gambaran negatif tentang tentang diri sendiri. Anak merasa malu dan rendah diri dan yakin bahwa yang terjadi pada dirinya adalah karena adanya sesuatu yang memang salah dengan dirinya tersebut (misal melihat diri anak sial); d) Traumatis seksual. Pemaparan pengalaman seksual terlalu dini, juga yang terjadi secara salah dapat berdampak pada munculnya trauma seksual. Trauma seksual dapat tertampilkan dalam dua bentuk inhibisi seksual yakni hambatan-hambatan untuk dapat tertarik dan menikmati seks atau justru disinhibisi.

\section{Perlindungan Hukum Terhadap Anak Yang Mendapatkan Kekerasan}

Banyaknya kasus mengenai kekerasan terhadap anak yang terjadi di indonesia dianggap sebagai suatu indikator buruknya kualitas perlindungan anak. Keberadaan anak yang belum mampu untuk hidup mandiri tentunya sangat membutuhkan orang-orang sebagai tempat berlindung bagi anak. Rendahnya kualitas perlindungan anak di indonesia banyak menuai sorotan dan kritik dari berbagai lapisan masyarakat.

Fenomena kejahatan berupa tindak kekerasan yang terjadi pada anak-anak di indonesia mulai menuai sorotan keras dari berbagai kalangan pada saat banyak stasiun televisi swasta menayangkan secara vulgar pada program kriminal seperti kasus perkosaan dan pencabulan yang dilakukan oleh keluarga korban atau orang-orang dekat korban, kasus sodomi, perdagangan anak untuk dieksploitasi menjadi pekerja seks komersil hingga pembunuhan. Masalah perlindungan terhadap anak sebagai korban kekerasan bukan masalah yang mudah untuk kita praktekkan dalam kenyataan di kehidupan sehari-hari.

Setiap terjadinya suatu kejahatan dimulai dari kejahatan ringan sampai kejahatan yang berat sudah tentu akan menimbulkan korban dan korbannya tersebut akan mengalami penderitaan baik yang bersifat materiil maupun inmateriil khususnya dalam kasus kekerasan terhadap anak yang dimana anak sebagai korban dan tidak semestinya mendapatkan perlakuan yang salah tersebut dikarenakan 
setiap anak memiliki hak yang terkandung dalam Undang-Undang No 23 Tahun 2002 tentang Perlindungan Anak yang meliputi: a) Setiap anak berhak untuk hidup, tumbuh, berkembang dan berpartisipasi secara wajar sesuai dengan harkat dan martabat kemanusiaan serta mendapat perlindungan dari kekerasan dan diskriminasi; b) Setiap anak berhak atas suatu nama sebagai identitas diri dan status kewarganegaraan; c) Setiap anak berhak untuk beribadah menurut agamanya, berpikir dan berekspresi sesuai dengan tingkat kecerdasan dan usianya dalam bimbingan orangtuanya; d) Setiap anak berhak untuk mengetahui orangtuanya, dibesarkan dan diasuh oleh orangtuanya sendiri. Dalam hal karena suatu sebab orangtuanya tidak dapat menjamin tumbuh kembang anak atau anak dalam keadaan terlantar maka anak tersebut berhak diasuh atau diangkat sebagai anak asuh atau anak angkat oleh orang lian sesuai dengan ketentuan peraturan perundang-undangan yang berlaku; e) Setiap anak berhak memperoleh pelayanan kesehatan dan jaminan sosial sesuai dengan kebutuhan fisik, mental, spiritual dan sosial; f) Setiap anak berhak memperoleh pendidikan dan pengajaran dalam rangka pengembangan pribadinya dan tingkat kecerdasannya sesuai dengan minat dan bakatnya. Khusus bagi anak penyandang cacat juga berhak memperoleh pendidikan luar biasa sedangkan bagi anak yang memiliki keunggulan juga berhak mendapatkan pendidikan khusus; g) Setiap anak berhak menyatakan dan didengar pendapatnya, menerima, mencari dan memberikan informasi sesuai dengan tingkat kecerdasan dan usianya demi pengembangan dirinya sesuai dengan nilai-nilai kesusilaan dan kepatutan; h) Setiap anak berhak untuk beristirahat dan memanfaatkan waktu luang, bergaul dengan anak sebaya, bermain, berekreasi dan berekreasi sesuai dengan minat, bakat dan tingkat kecerdasannya demi pengembangan diri; i) Setiap anak yang menyandang cacat berhak memperoleh rehabilitasi, bantuan sosial dan pemeliharaan taraf kesejahteraan sosial; j) Setiap anak selamadalam pengasuhan orangtua, wali atau pihak lain manapun yang bertanggungjawab atas pengasuhan, berhak mendapat perlindungan dari perlakuan diskriminasi, eksploitasi baik ekonomi maupun seksual, penelantaran, kekejaman, kekerasan dan penganiayaan, ketidakadilan dan perlakuan salah lainnya. Setiap orang yang melakukan segala bentuk perlakuan itu dikarenakan pemberatan hukum; k) Setiap anak berhak untuk diasuh oleh orangtuanya kecuali jika ada alasan dan/atau aturan hukum yang sah menunjukkan bahwa pemisahan itu adalah demi kepentingan terbaik bagi anak dan merupakan pertimbangan terakhir; 1) Setiap anak berhak untuk memperoleh perlindungan dari penyalahgunaan dalam kegiatan politik, pelibatan dalam sengketa bersenjata, pelibatan dalam kerusuhan sosial, peibatan dalam peristiwa yang mengandung unsur kekerasan dan pelibatan dalam peperangan; m) Setiap anak berhak memperoleh perlindungan dari sasaran penganiayaan, penyiksaan atau penjatuhan hukuman yang tidak manusiawi. Setiap anak berhak untuk memperoleh kebebasan sesuai dengan hukum. Penangkapan, penahanan atau tindak pidana penjara anak hanya dilakuakn apabila sesuai dengan hukum yang berlaku dan hanya dapat dilakukan sebagai upaya terakhir; n) Setiap anak yang dirampas kebebasannya berhak untuk mendapatkan perlakuan secara manusiawi dan penempatannya dipisahkan dari orang dewasa, memperoleh bantuan hukum atau bantuan lainnya secara efektif dalam setiap tahapan upaya hukum yang berlaku. Dan membela diri dan memperoleh keadilan di depan pengadilan anak yang objektif dan tidak memihak dalam sidang tertutup untuk umum. Setiap anak yang menjadi korban atau pelaku kekerasan seksual atau yang berhadapan dengan hukum berhak dirahasiakan; o) Berhak mendapatkan bantuan hukum dan bantuan lainnya.

Aspek perlindungan terhadap anak korban kekerasan merupakan usaha atau kegiatan bersama yang bertujuan untuk mengusahakan pemenuhan hak anak dalam menjamin kemerdekaan hak asasinya. Usaha perlindungan anak akibat kekerasan menekankan pemahaman terhadap penegakan peraturan yang sudah ada dengan melibatkan unsur kepentingan bersama dan usaha bersama. Masalah perlindungan anak korban kekerasan mencakup aspek perlindungan hak asasi anak dan kebebasan anak pada tahap perkembangnnya. Dengan adanya Undang-Undang No. 23 Tahun 2002 tentang Perlindungan Anak merupakan alat hukum yang mampu untuk melindungi anak dalam berbagai tindak pidana khususnya kekerasan seksual terhadap anak. Undang-undang tersebut menyatakan 
bahwa kekerasan seksual terhadap anak merupakan tindak pidana sehingga pelaku dapat diajukan ke kepolisian atas pendampingan pihak terkait.

Ditinjau dari Undang-Undang No. 23 Tahun 2002 tentang Perlindungan Anak Pasal 3 dinyatakan bahwa: "Perlindungan anak adalah segala kegiatan untuk menjamin hak-hak anak agar dapat hidup, tumbuh, berkembang dan berpartisipasi secara optimal sesuai dengan harkat dan martabat kemanusiaan, serta mendapat perlindungan dari kekerasan dan diskriminasi." lain:

Adapun perlindungan yang diberikan terhadap anak yang menjadi korban tindak pidana antara

1. Perlindungan langsung

Dalam hukum nasional perlindungan anak telah memperoleh dasar pijakan yuridis diantaranya Undang-Undang Dasar 1945 sebagai landasan konstitusional Anak serta UndangUndang No. 23 Tahun 2002 tentang Perlindungan Anak.

Pasal 28B ayat 2 Undang-Undang Dasar 1945 dengan tegas menyebutkan: "setiap anak berhak atas perlindungan dari kekerasan dan diskriminasi."

Selanjutnya dalam Undang-Undang No. 23 Tahun 2002 tentang Perlindungan Anak memberikan pengaturan yang jelas dan komperhensif tentang perlindungan anak yang pada pokoknya bertujuan memberikan jaminan dan melindungi anak dan hak-haknya agar dapat hidup, tumbuh dan berkembang serta berpartisipasi secara optimal sesuai dengan harkat dan martabat kemanusiaan serta memperoleh perlindungan dari kekerasan dan diskriminasi.

Dalam Pasal 59 Undang-Undang No 23 Tahun 2002 tentang Perlindungan Anak bagian dari perlindungan secara khusus, baik anak yang menjadi korban kejahatan maupun anak dalam keadaan darurat bahkan juga diatur perihal kewajiban dan tanggung jawab pemerintah dan lembaga negara lainnya akan tetapi dalam penelitian ini hanya untuk memberikan perlindungan khusus kepada anak korban kejahatan berupa kekerasan.

Perlindungan khusus bagi anak korban kekerasan meliputi kekerasan fisik, psikis, dan seksual dilakukan melalui upaya:

a. Penyebarluasan dan sosialisasi ketentuan peraturan perundang-undangan yang melindungi anak korban tindak kekerasan

b. Pemantauan, pelaporan dan pemberian sanksi

Undang-undang melarang setiap orang menempatkan, membiarkan, melakukan menyuruh melakukan atau turut serta melakukan kekerasan sebagaimana dimaksudkan undang-undang ini.

2. Perlindungan tidak langsung

Untuk dapat memperkuat upaya perlindungan langsung kepada anak-anak yang dapat membutuhkan perlindungan khusus, diperlukan program-program penunjang sebagai berikut:

a. Penyediaan perangkat-perangkat hukum yang diperlukan untuk mendukung perlindungan anak seperti:

1) Penyusunan berbagai peraturan pemerintah atau keppres yang menjabarkan perangkatperangkat undang-undang yang telah dimiliki

2) Peraturan-peraturan daerah yang dapat mencegah, melindungi dan mempromosikan anakanak serta secara keseluruhan dan khususnya anak-anak yang membutuhkan perlindungan khusus 
b. Penegakan hukum oleh aparat penegak hukum terhadap berbagai kasus pelanggaran anak dan perlindungan terhadap anak yang membutuhkan pelindungan khusus yang bersumber pada peraturan perundang-undangan yang berlaku dan relevan dengan masalah anak

c. Advokasi mengenai perubahan-perubahan kebijakan dan program yang mendukung bagi upaya pencegahan dan perlindungan anak-anak yang membutuhkan perlindungan khusus. Advokasi dilakukan kepada semua pengambil keputusan pada sektor-sektor pemerintah yang terkait dengan permasalahan ini

d. Pengembangan sistem informasi yang menyediakan berbagai informasi perlindungan anak yang terus menerus diperbaharui dari berbagai laporan-laporan kasus pelanggaran hak anak. Jenis informasi yang disediakan mencakup permasalahan perlindungan anak dan program-programnya serta laporan-laporan yang relevan, sistem informasi terbuka diakses diluar.

e. Pelatihan dan pengembangan kapasitas bagi para penyedia pelayanan perlindungan anak, baik para pekerja LSM, aparatur penegak hukum dan birokrasi pemerintah yang terkait, kegiatan ini ditunjukkan untuk meningkatkan kemampuan mereka dalam mengatasi berbagai masalah perlindungan anak

f. Penyadaran masyarakat agar mereka mempunyai daya tanggap dan tindakan dalam upaya mencegah dan melindungi anak yang membutuhkan perlindungan khusus. Penyadaran masyarakat dilakukan melalui sosialisasi dan kampanye baik secara terbuka melalui media massa maupun media tradisional.

g. Pendidikan orangtua melalui penyuluhan, bimbingan maupun pelatihan agar mereka dapat meningkatkan kemampuan dalam memenuhi hak-hak anak dan mempunyai daya tanggap terhadap keadaan lingkungan sekitarnya.

h. Pengembangan jaringan kerja, dengan berbagai lembaga pemerintah, LSM, maupun perguruan tinggi yang mempunyai tanggungjawab dan peranan yang dalam perlindungan anak-anak yang membutuhkan perlindungan khusus sesuai dengan tugas pokok dan fungsinya.

Didalam Undang-Undang No 23 Tahun 2002 tentang Perlindungan Anak menegaskan bahwa pertanggungjawaban orangtua, keluarga, masyarakat, pemerintah dan negara merupakan rangkaian kegiatan yang dilakukan secara terus menerus demi terlindungnya hak-hak anak.

\section{KESIMPULAN}

Penyebab terjadinya kekerasan terhadap anak memiliki beberapa faktor antara lain hambatan dalam perkembangan psikologi yang menyebabkan ketidakmampuan pelaku menjalani hubungan yang wajar, kecenderungan kepribadian anti sosial yang ditandai dengan hambatan perkembangan moral, terdapat kombinasi depresi, ketaktan yang berlebihan serta rendahnya tekananetika dan moral.

Bentuk perlinungan hukum terhdapa hak anak korban kekerasan dapat berupa perlindungan langsung dan tidak langsung antara lain, perlindungan langsung terdapat dalam Pasal 28B ayat 2 UUD 1945 dan Pasal 59 UU No. 23 Tahun 2002 tentang Perlindungan Anak. Bentuk prlindungan tidak langsung diperlukan program penunang seperti penyediaan perangkat hukum, penegakan hukum oleh aparat penegak hukum, advokasi mengenai perubahan kebijakan, pengembangan sistem informasi, pelatihan dan pengembangan kapasitas, penyadaran masyarakat agar mereka punya daya tanggap, pendidikan orangtua melalui penyuluhan bimbingan dan pelatihan serta pengembangan jaringan kerja dengan berbagai lembaga yang ada.

Dalam penanganannya anak harus mendapat perlindungan dan perhatian penuh baik dari orangtua, guru, masyarakat maupun pemerintah serta aparat penegak hukum, dan mereka tidak boleh melakukan kekerasan terhadap anak karena anak sebagai generasi penerus yang harus mendapat perlindungan 


\section{Daftar Pustaka}

Dewantara Agung Nanda, 1988, Kemampuan Hukum Pidana Dalam Menanggulangi Kejahatan-Kejahatan Baru Yang Berkembang Dalam Masyarakat, Yogyakarta, Liberty.

Gunarsa P Singgih, 1982, Psikologi Anak Bermasalah, BPK Gunung Mulia, Jakarta.

Ibrahim Husein, 1971, Kenakalan Anak. Penerbit Al-Ma'rif Bandung.

Kartono Kartini, 2001. Psikologi Sosial I. Rajawali Press Jakarta.

Moeljanto, 1985. Azas-Azas Hukum Pidana, PT. Bina Aksara. Jakarta.

Maidin Gultom, 2008. Perlindungan Hukum Terhadap Anak Dalam Sistem Peradilan Pidana Anak Di Indonesia, PT. Refika Aditama, Bandung.

Poerwardaminta WJS, 1984, Kamus Umum Bahasa Indonesia, PN Balai Pustaka. Jakarta

Soesilo R, 1994. Kitab Undang-Undang Hukum Pidana. Pelita Bogor.

Soekanto Soerjono, 1990, Sosiologi Suatu Pengantar, Jakarta, PT. Raja Grafindo Persada

Subekti, 1992, Kitab Undang-Undang Hukum Perdata, Pradnya Paramitha. Jakarta.

Sarwono Wirawan Sarlito, 2001. Psikologi Anak. PT. Grafindo Persada. Jakarta.

Syafarlin Sofian, 1975, Masalah Kenakalan Remaja Dan Penanggulangannya, Yogyakarta, Yayasan Karya Generasi Muda

Santoso Topo dan Anjani Eva, 2002, Kriminologi, PT. Raja Grafindo Persada. Jakarta.

Vredenbreght, J, 1980, Metode dan Tehnik Penelitian Masyarakat, Penerbit PT. Gramedia

Peraturan Perundang-Undangan

Kitab Undang-Undang Hukum Pidana

Undang-Undang No. 23 Tahun 2002 Tentang Perlindungan Anak

Undang-Undang No. 3 Tahun 1997 Tentang Peradilan Anak

Undang-Undang No. 39 Tahun 1999 Tentang Hak Asasi Manusia

Karya Ilmiah

Deni Setiawan, Kajian Hak Asasi Manusia di Indonesia, www.hukumonline.com

Wahyu Wiriono, Kajian Peradilan Anak, www.hukumonline.com

R. Gautama Widodo, Kajian Tindak Pidana Anak Di Indonesia, www.darmais.com

Artikel Internet "Kejahatan Anak Tanggung Jawab Siapa?”. 